\title{
Correction to: Consumer dynamics: theories, methods, and emerging directions
}

\section{Jonathan Z. Zhang ${ }^{1}$ (D) $\cdot$ Chun-Wei Chang ${ }^{2}$}

Published online: 23 April 2020

(C) Academy of Marketing Science 2020

\section{Correction to: Journal of the Academy of Marketing Science} https://doi.org/10.1007/s11747-020-00720-8

Since this paper was first published, the publisher has been informed of an additional contributing author, Chun-Wei Chang. No other changes have been made to the text.

The original article has been corrected.

Publisher's note Springer Nature remains neutral with regard to jurisdictional claims in published maps and institutional affiliations.

The online version of the original article can be found at https://doi.org/ 10.1007/s11747-020-00720-8

$\triangle$ Jonathan Z. Zhang

jonathan.zhang@colostate.edu

Chun-Wei Chang

chunwcha@amazon.com

1 Colorado State University, Fort Collins, CO 80523, USA

2 Amazon.com, Seattle, WA 98109, USA 